\title{
Multidisciplinary Monitoring of the Entire Life Span of an Earthquake in South African Gold Mines
}

\author{
H. Ogasawara, J. Takeuchi, N. Shimoda Faculty of Science and Engineering, Ritsumeikan University, Japan \\ M. Nakatani, A. Kato Earthquake Research Institute, The University of Tokyo, Japan \\ Y. lio, H. Kawakata, T. Yamada Disaster Prevention Research Institute, Kyoto University, Japan \\ T. Yamauchi Graduate School of Environmental Studies, Nagoya University, Japan \\ H. Ishii Tono Research Institute of Earthquake Science, Japan \\ T. Satoh, K. Kusunose Institute of Geoscience, National Institute of Advanced Industrial Science and Technology, Japan \\ K. Otsuki, S. Kita Graduate School of Science, Tohoku University, Japan \\ S. Nakao Faculty of Science, Kagoshima University, Japan \\ A.K. Ward Seismogen CC, South Africa \\ R.B. McGill Mponeng Mine, South Africa \\ S.K. Murphy Tau Tona Mine, South Africa \\ A.J. Mendecki, G. van Aswegen ISS International Ltd, South Africa
}

The Research Group for Semi-Controlled Earthquake-Generation Experiments in South African Deep Gold Mines

Since 1992, the authors attempted to monitor stress, its build-up and strength at $M>\sim 2$ hypocentres in South African deep gold mines. In the second field experiment, the authors successfully monitored the entire strain history within a hundred metres from the hypocentres, associated with a few seismic events with $M>2$. However, there were no close strong-motion meters available to locate asperities; only a single strainmeter was available, so the authors were not able to locate the strain-change source; no in situ stress measurements were carried out at the site, and no information was available to constrain strength. In order to address these deficiencies, from 2003 to 2004, the authors deployed new experimental instrument arrays at fault bracket/stabilising pillars. Multiple strainmeters, arrays of strong ground-motion meters, sensitive thermometers to monitor seismic heat generation, and fault displacement meters were installed. Successful monitoring began, but the authors learnt that they had to develop instruments for much quicker drilling and installation, especially at highly stressed pillars adjacent to mining operations.

\section{INTRODUCTION}

After the 1995 Kobe earthquake, which caused more than 6,000 fatalities, dense nationwide arrays of strong-groundmotion meters, highly sensitive seismometers and GPS were deployed in Japan, in order to monitor earthquake-generation processes in detail. One of the principal results of this monitoring was discovering the role of asperities and the role of the surrounding area, both before and after large events (e.g. Iio et al., 2003). However, the interaction of asperities or initiation of rupture are still not fully understood, because hypocentres are too distant to observe in detail even with sensitive, low-noise instruments that are in place for years, even with a high-resolution recording system. The stress and strength at the hypocentre are still fundamental parameters that have never been monitored directly. In addition, large events occur too infrequently to allow us to learn about them within a short time period.

However, in order to monitor frequent seismic events, we can most closely approach hypocentral areas in deep mines. Although stress is well controlled during mining (e.g. Ryder and Jager, 1999, 2002), not enough direct, high-resolution monitoring of stress, and its build-up and strength, has been done in hypocentral areas of potentially hazardous seismic events. However, with sensitive, low-noise, stable instruments for monitoring natural earthquakes, pioneering work was done by the group headed by Art McGarr in the 1970s - 80s (e.g. McGarr et al., 1982). With a modern, higher-resolution recording system, the Research Group for Semi-controlled Earthquake-generation Experiments in South African deep gold mines has attempted to monitor earthquakes since 1992 (Nicolaysen, 1992; Iio and Fukao 1992; Iio, 1995; Sumitomo, 1998; Ogasawara et al., 2001, 2002). ISS International Ltd. has helpfully collaborated in high-resolution monitoring as well as seismic monitoring (e.g. Mendecki, 1993, 1997).
Recently, this group has successfully used a sensitive strainmeter to monitor interesting strain changes within a hypocentral area (e.g. Takeuchi et al. 2003; Ogasawara et al., 2005). However, there were no nearby strong-motion meters available to locate asperities; only a single strainmeter was available, which was not sufficient to locate the strain-change source; no in situ stress measurements were carried out at the site.

In order to address these deficiencies, from 2003 to 2004 we deployed two new experimental instrument arrays at fault bracket/stabilising pillars in the Tau Tona and Mponeng gold mines, South Africa. Heat generation associated with seismic events can be effective in constraining fault strength. Our study also attempted to monitor temperature change.

We had difficulties drilling in a highly stressed stabilising pillar with both sides mined, and we describe this below. Next, we describe how drilling and instrument deployment went smoothly at a planned fault bracket pillar with only a mined waste slot. We also mention the necessity of developing instruments for much quicker drilling and installation.

\section{EXPERIMENTAL SITE AT A FAULT STABILISING PILLAR WITH BOTH SIDES BEING MINED}

\subsection{Site Description}

One of our new experimental sites was located at a faultstabilising pillar about $2.9 \mathrm{~km}$ deep in the Tau Tona mine (Figure 1). The following characteristics occur around this site:

- The gold reef dips southeastward at an angle of about 20 degree (see two dipping plates in Figure 1, in which the solid and mined portions are represented by a mottled pattern and black, respectively). 
- Two normal faults dip northwestward, intersecting the gold reef with a total throw of about $40-50 \mathrm{~m}$ (two light-grey planes in Figure 1).

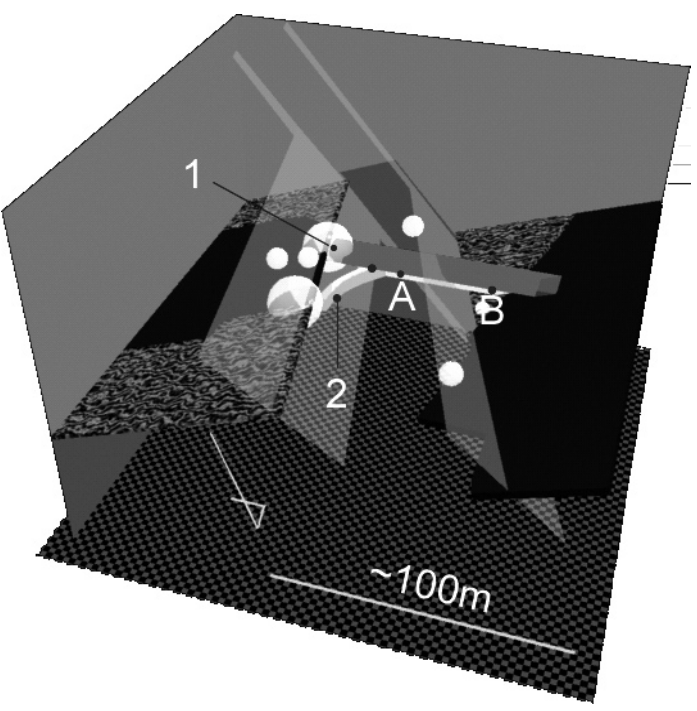

FIG. 1 Simplified schematic illustration representing 3D configuration of gold reef intersected by two faults (light grey). Access tunnel (white) is capped with a waste slot (dark grey), forming a so-called T-shaped slot. See details in text

- The eastern fault was sufficiently exposed at the intersection of a tunnel and a waste slot (Points 1 and 2 in Figure 1), and characterised by a $\sim 30 \mathrm{~cm}$ thick, coarsely fractured zone. Both sides of the zone were laminated with finely-fractured flakes less than 1 $\mathrm{cm}$ thick, suggesting fresh fracturing. Slight water seepage was evident locally. The western fault was not exposed well, but was definitely located at the T-shaped slot.

- A so-called T-shaped slot, consisting of a tunnel capped by a wider waste-slot about $1 \mathrm{~m}$ thick and $15 \mathrm{~m}$ wide (in Figure 1, a white, horizontal prism and a medium-grey, narrow plate laid horizontally on the prism), was excavated across two faults.

- A gold reef on the northwestern side of the bracket pillar had previously been mined.

- Figure 1 shows the situation in August 2003. Full-scale mining of the gold reef on the southeastern side of the pillar began at the end of 2002, and advanced toward the northeast. An M2 event occurred in March 2003 and another in August 2003 (southern and northern larger spheres in Figure 1, respectively) and another occurred in October 2003 (not shown in Figure 1).

- The country rock is quartzite with a typical Young's modulus of $70 \mathrm{GPa}$.

Any information on stress and strength in the above situation is very crucial for understanding an earthquake source and for effective and safe mining. So, two cubbies (small chambers $2.5 \mathrm{~m}$ high $\times 3 \mathrm{~m}$ wide $\times 5 \mathrm{~m}$ deep) were excavated by blasting (A and B in Figure 1) for drilling space. Our original plan was to drill several holes $15-30 \mathrm{~m}$ long, in order to install two strainmeters to monitor shear and normal strain changes on the fault, to install multiple strong groundmotion meters to locate asperities, and to carry out stress measurement beforehand.

\subsection{In situ Stress Measurement}

In addition to continuous monitoring of strain change as we have done at the second experimental site (Ogasawara et al., 2005), we tried to measure stress beforehand: direct measurement with overcoring (2.2.1) and indirect measurement with a borehole camera and cores (2.2.2).

\subsubsection{Overcoring with an intelligent, recoverable Ishii strain meter}

We used an intelligent Ishii strainmeter (Figure 2), which has an A/D converter, a microprocessor, memory and rechargeable batteries (e.g. Yamauchi et al., 2000). It enables wireless overcoring even in a deep, vertical borehole, $1 \mathrm{~km}$ being the deepest one known (e.g. Matsumoto et al. 2000, Ishii et al. 1997, 2002). We specially designed this strainmeter to be installed in a BX hole (60 $\mathrm{mm}$ diameter), and it has eight components to enable us to measure three-dimensional stress by a single overcoring. The power consumption of the strain cell is very low and we can schedule operation of the measurement system, enabling monitoring for a long period. Therefore, if we leave a recovered core for a while with the strain-cell inside, we can monitor inelastic expansion. In addition, pressure calibration is easily done if we put the recovered core into a pressure vessel. No underground wire connection is needed. Everything except installation and overcoring can be done on the surface.

Figure 3 schematically illustrates the installation and overcoring procedure. The strain cell is inserted in a BX hole (60 $\mathrm{mm}$ diameter) with grout (Figure $3 \mathrm{a}$ and $\mathrm{b}$ ). After the grout has set, the hole is reamed to a diameter of $114 \mathrm{~mm}$ (49/16 size), followed by overcoring with a double-core-tube barrel. Although we had difficulty in drilling the shallower part, we successfully drilled a BX hole $15 \mathrm{~m}$ long. The core for the last few metres had no disking. With a borehole camera,

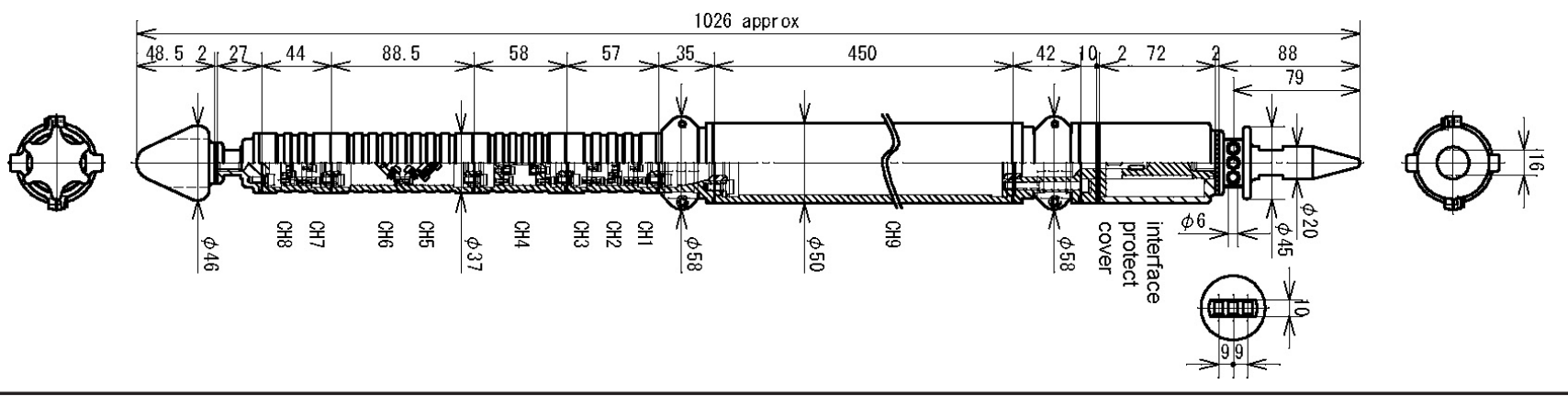

FIG. 2 An 8-component intelligent Ishii strainmeter (FS-4022, Makome Corp. Japan). Chs. 1-3: borehole-normal components, Ch. 4: borehole-parallel component, Chs.5 \& 6: borehole-oblique components, Chs. 7-8: same as Chs.1\&2 for redundancy. Ch.9: quartz thermometer. The strainmeter has an $A / D$ converter, a microprocessor, memory and rechargeable batteries, enabling wireless overcoring 


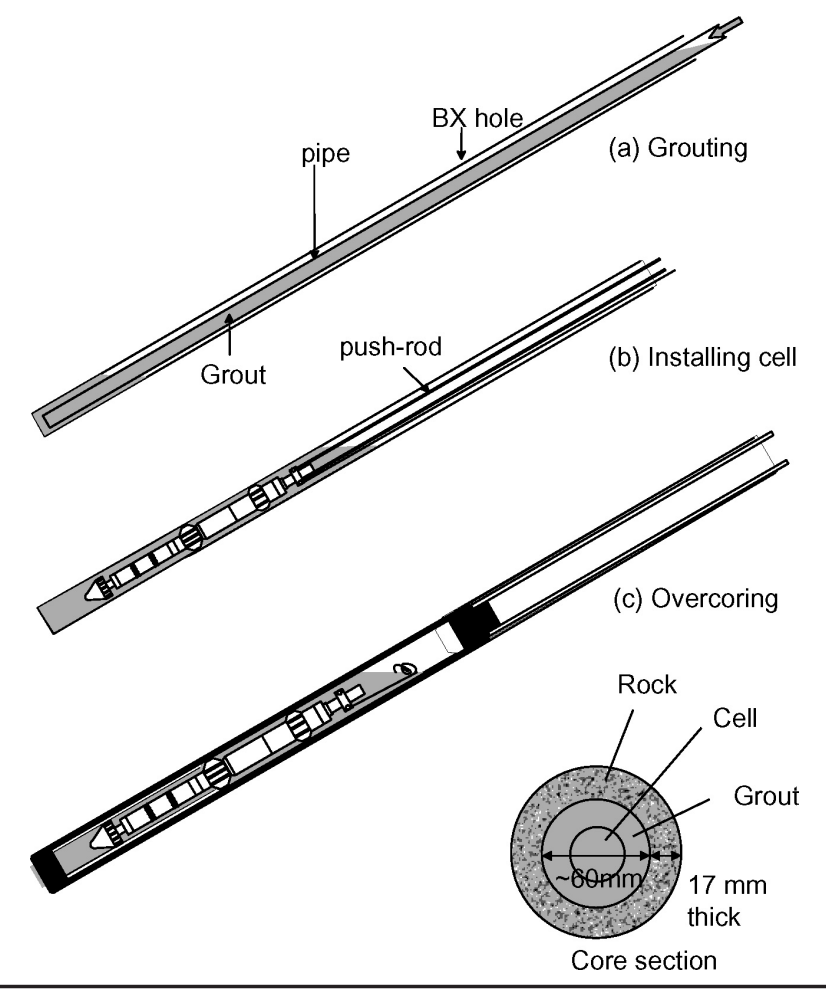

FIG. 3 Schematic illustration of installation and overcoring procedures for an intelligent, recoverable Ishii strainmeter

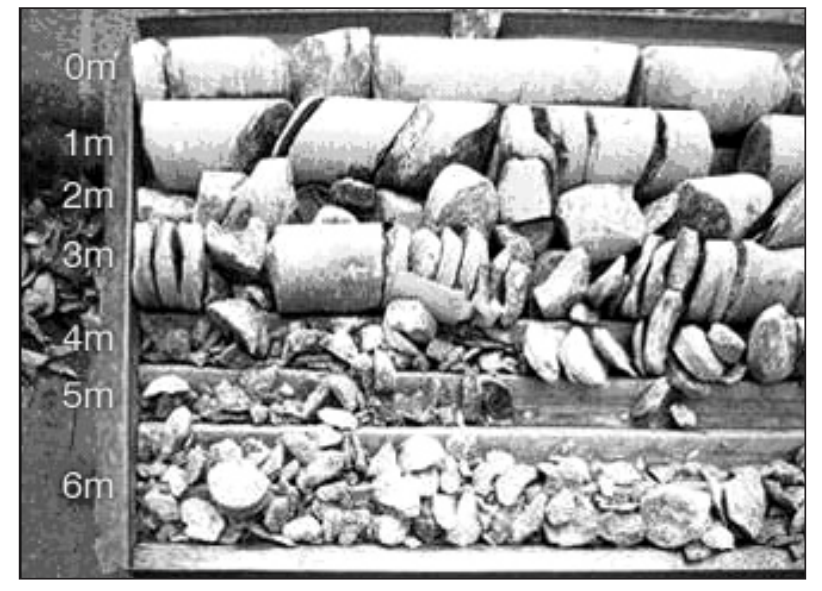

FIG. 4 An example of highly fractured BX core

we confirmed that there was no borehole breakout in the last few metres. We installed a strainmeter at a depth of $15 \mathrm{~m}$ in late June 2003.

\subsubsection{Fracturing from high stress and difficulty in drilling}

Generally, the highest stress is located several metres from the tip of a thin, tabular cavity (e.g. Jager and Ryder 1999, 2002) Thus, we had serious fracturing at a depth of several metres from the edge of the T-shaped slot. Figure 4 shows typical examples of a BX drill core. With an increase in stress, the core was disked ( $\sim 3 \mathrm{~m}$ deep in Figure 4$)$ and eventually crushed (4-6 m deep in Figure 4). At a depth of $6-7 \mathrm{~m}$, borehole breakout enlarged hole diameter considerably (dashed circle in Figure 5), which made accurate reaming or overcoring difficult. We tried to repair the hole, but eventually gave up overcoring in November 2003.

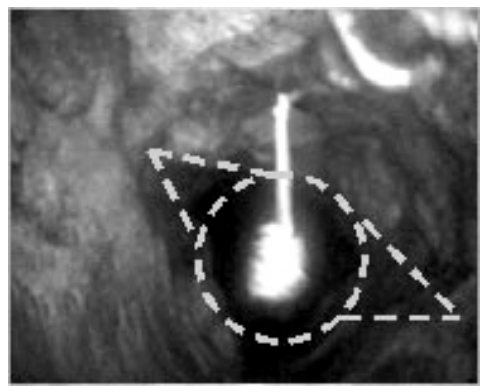

FIG. 5 Typical borehole camera image at a depth of 6 - $7 \mathrm{~m}$. Original hole and break out are indicated by dashed grey circle and lines. White string with mass is a vertical marker

\subsubsection{Indirect stress measurement}

We successfully recovered a core at the depth of interest and tried to monitor 'anelastic strain recovery' (ASR method; e.g. Amadei and Stephansson, 1997). However, no significant ASR was observed, possibly because of the relatively low porosity of quartzite.

We also tried the 'differential strain curve analysis' method (DSCA; e.g. Amadei and Stephansson, 1997), but failed. When a sample was subjected to hydrostatic pressure, the dominant orientation of microcrack closure was boreholeparallel. Evidently the closure direction was controlled by invisible cracks of core-disking origin.

Both sides of the borehole wall were wedged (see dashed line wedges in Figure 5) by borehole breakout (e.g. Amadei and Stephansson, 1997). This suggests a direction of maximum principal stress oblique to the fault plane. From June to August 2003, we observed that the extent of borehole breakout increased along with the advance of mining on the southeastern side of the pillar. Two $\mathrm{M}>2$ events took place in August and October 2003 within $100 \mathrm{~m}$ of the borehole. Therefore, repeated observations of an open hole might be the best method to learn about stress states under very highstress conditions.

\subsection{Final Monitoring Configuration}

Despite difficulties in drilling, we successfully installed strong-ground-motion meters at a depth of $10 \mathrm{~m}$ in two cubbies (A and B in Figure 1), and a strain meter at a depth of $7 \mathrm{~m}$ in Cubby A.

\section{EXPERIMENTAL SITE AT A PLANNED FAULT- BRACKET PILLAR WITH ONLY A WASTE SLOT BEING MINED}

In contrast to the above-mentioned experimental site that had conditions of considerable stress, an experimental site $2.9 \mathrm{~km}$ deep in the Mponeng mine was affected little by a concentration of high stress. This site was located at a planned fault-bracket pillar. Figure 6 schematically illustrates the three-dimensional configuration of tunnels, the gold reef and the Pretorius fault zone. Only a waste slot about $50 \mathrm{~m}$ wide was excavated along the gold reef to protect the crosscut tunnel. Our target area, indicated by a square in Figure 6, is characterised by a dense, existing geophone array surrounding the site.

\subsection{Target Area with a Distinctive Weak Plane}

In the target area, eleven holes 5-30 m long were drilled smoothly, because stress was not yet seriously concentrated. Figure 7 illustrates the configuration of boreholes and our target weak plane. Our site was located within the Pretorius fault zone, which is several tens of metres wide and consists 


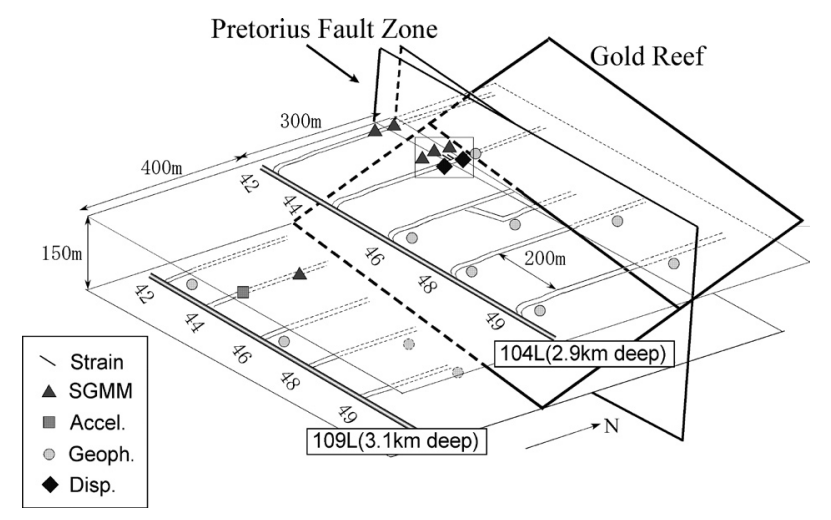

FIG. 6 Three-dimensional configuration of tunnels, gold reef and the Pretorius fault zones. A small square: our target is located near an intersection of the 104/44 crosscut tunnel and the fault

of complex geology in the country rock (basaltic lava on the hangingwall and quartzite on the foot wall), along with fragmented patches and fill-ups with cataclasite. We located many weak planes on the sidewall of the tunnel: e.g. K, A1 and $\mathrm{M}$ are major ones in Figure 7. Among these, we have identified a single continuous weak plane (dotted grey line in Figure 7), which bounds the southern end of the fault zone at this locality (Kita et al., 2004). This scenario is suggested by the following observations of the cores and tunnel wall, and by borehole camera records (Nakatani et al., 2004):

- A narrow $(2-20 \mathrm{~cm})$, severely damaged zone (stars in Figure 7) on the borehole wall was recognised in all of the five holes penetrating through this plane. Rock material was lost from the borehole wall at these damage zones.

- This damage was found to be restricted to a fairly flat plane extending from a $20 \mathrm{~cm}$-thick shear zone exhumed on the tunnel wall (labelled $\mathrm{M}$ ).

- Core material recovered from this plane, as well as from plane M exhumed in the tunnel, is weak (friable).

South of this boundary there is a single lithology consisting of basaltic lava, while the lithology to the north of this boundary is complex, including 2.0 to $300 \mathrm{~cm}$ thick layers of quartzite, cataclasite, and lava, in variable sequences.

\subsection{Direct Measurement of Frictional Heating by Earthquake Slip (Nakatani et al., 2004)}

\subsubsection{Experimental design}

The site provided us a rare opportunity to install thermometers to monitor the frictional heat of a forthcoming earthquake. Heat conduction in rocks is very slow; it takes a week for the temperature $1 \mathrm{~m}$ from the heat source (slip plane) to reach a peak, followed by much slower cooling. The slower the change is, the more difficult becomes the separation from background noise and instrument drift. Time to peak values increases with the square of the source's distance.

Assuming a $2 \mathrm{~cm}$ slip at a $50 \mathrm{MPa}$ frictional resistance, the magnitude of the temperature rise is about $0.15 \mathrm{~K}$. The magnitude is proportional to generated heat and inversely proportional to source distance.

Taken together with the time-to-peak value mentioned above, difficulty increases with the cube of source distance. We have set our target value of heating equivalent to a $2 \mathrm{~cm}$ slip at $5 \mathrm{MPa}$, so that we can detect the heat signature even if the fault friction is much lower than laboratory values (Byerlee, 1978), as has sometimes been proposed

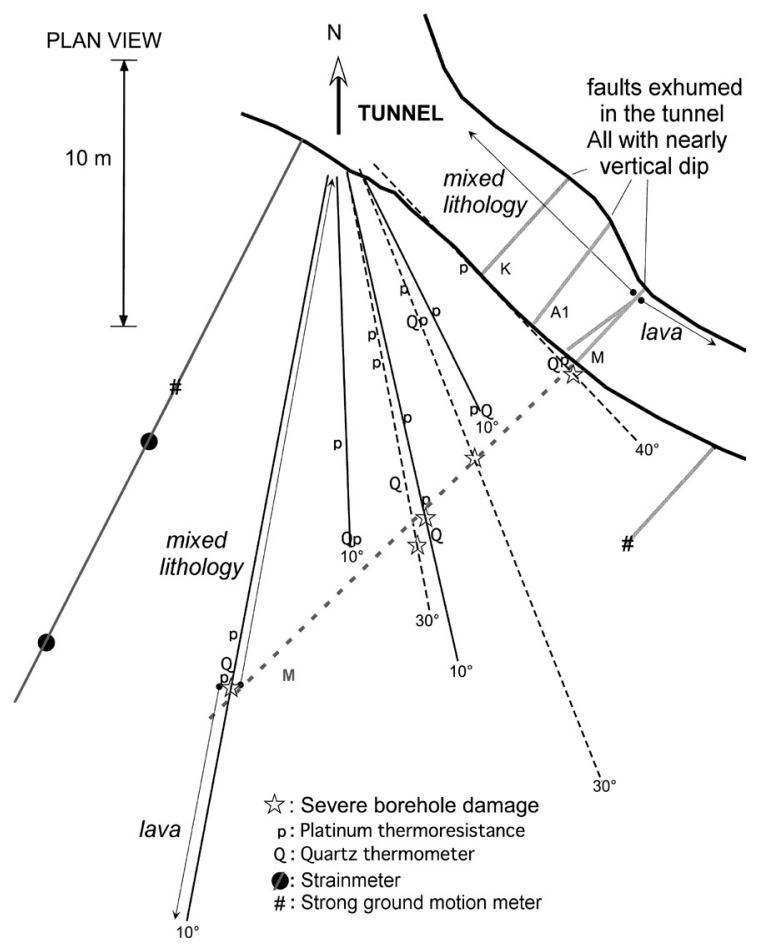

FIG. 7 A plan view map illustrating configuration of boreholes, with locations of sensors and relevant geological features (Modified from Nakatani et al., 2004)

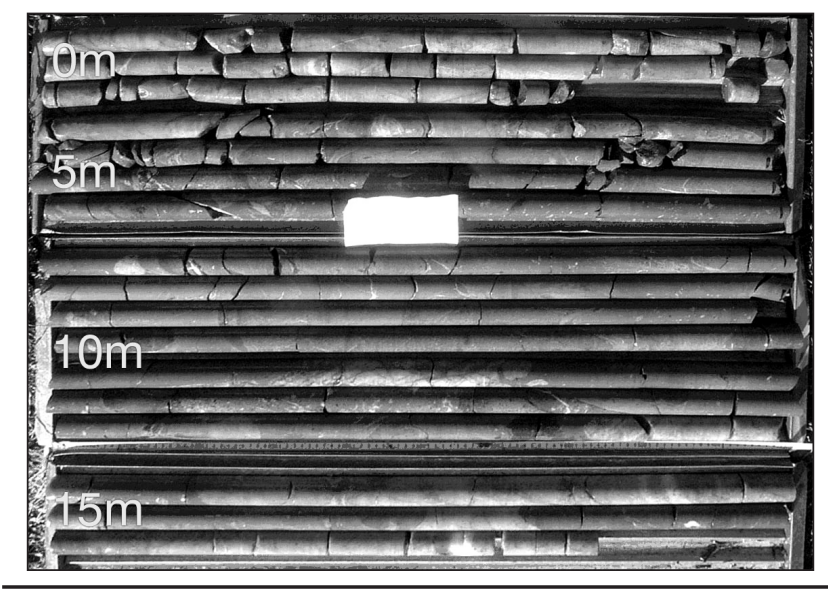

FIG. 8 An example of drill core from a strainmeter hole (a line with solid circles in Figure 7) at Mponeng mine

(e.g. Lachenbach and Sass, 1980). We estimate that sensors must be installed within a metre of the fault to achieve this, and our installation was successful.

\subsubsection{Sensor layout}

Two types of sensors have been installed as shown in Figure 7. Many were placed to cover a significant extent $(15 \mathrm{~m} \times 6 \mathrm{~m})$ of the discrete weak plane mentioned above, in order to check the uniformity of frictional heating. Some were laid close to two possible minor slip planes (K and A1) in case slip occurred along them. Records obtained so far indicate a slow cooling (0 to $6 \mathrm{mK} /$ day), presumably due to tunnel development (two years ago) and air conditioning following it. The trend of this long-term cooling is linear and is easy to remove from our results, so that we are likely to detect temperature rises of the extent discussed earlier. 


\subsection{Strain, Fault Displacement and Strong-Motion Monitoring}

Figure 8 shows the BX core from a strainmeter hole (a line with two solid circles in Figure 7). In contrast to highly fractured core at Tau Tona, the core exhibited little fracture. We successfully installed two strainmeters (solid circles in Figure 7) at depths of $13 \mathrm{~m}$ and $25 \mathrm{~m}$, with which we monitored shear and normal strains in the fault zone. Figure 9 shows an example of strain recordings with two seismic events and blasting-induced drift that lasted for a 30 -s period on the order of $10^{-7}$. As these were recorded clearly with the multiple strainmeter, we can confidently discuss them in detail. Faultdisplacement meters were installed at $\mathrm{K}$ and $\mathrm{M}$ in Figure 7. Two strong-motion meters were installed as shown by \# in Figure 7 . With these instruments we can monitor the entire life span of an earthquake.

\section{PRACtical Strategy}

Figure 10 shows seismicity within cubes $500 \mathrm{~m}$ on a side and centred on strainmeters in the Tau Tona and Mponeng mines. We started drilling in May 2003 at Tau Tona and in June 2003 at Mponeng, finishing the former in November 2003 and the latter in February 2004. After installation, monitoring was begun in March 2003 at both mines.

Meanwhile, significant seismicity, such as reported in our second experimental field, occurred at the Tau Tona mine. An $M>2$ event with a large strain step occur in October 2003. The fundamental modification in stress state by the event could not be monitored, because monitoring had not been started. In contrast to the Tau Tona mine, significant seismicity has not yet started near our sites at Mponeng. A large strain step was expected with a smaller event in October 2003, but it was not a large event that thoroughly disturbed the stress state. A larger event is still anticipated, and will be monitored with our dense array. The difference in the two mines was simply due to the speed and difficulty in drilling, which was

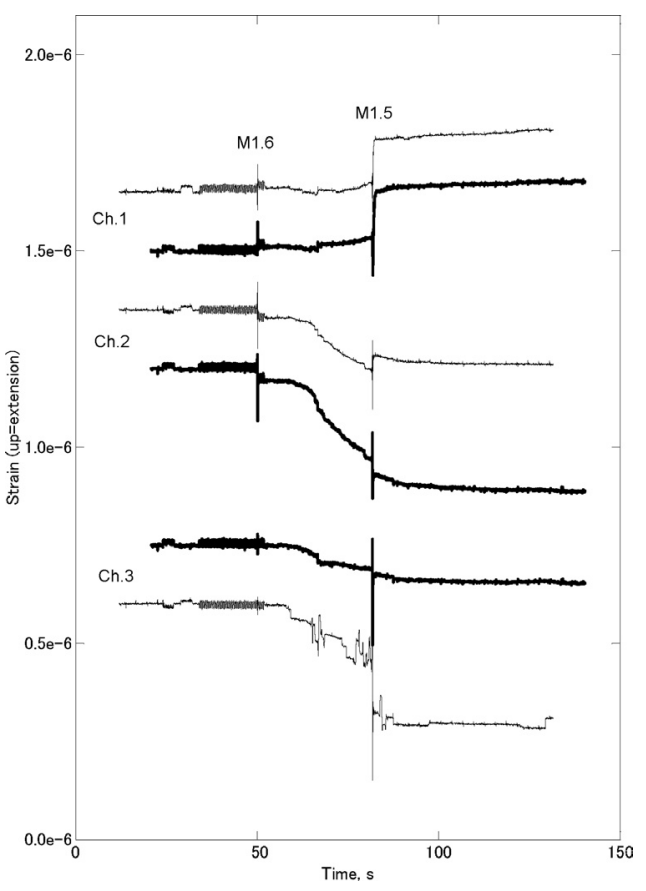

FIG. 9 An example of strain recordings for a two-minute period (12 Mar 2004) at Mponeng

dependent on the stress level. Even with the better conditions at Mponeng, however, our installation procedure was not quick enough.

In order to quantitatively monitor rockmass behaviour, quick drilling and installation are crucial to keep up with fast stress changes attending mining in South African gold mines. The instruments we imported from Japan were originally designed for long-term stability rather than for
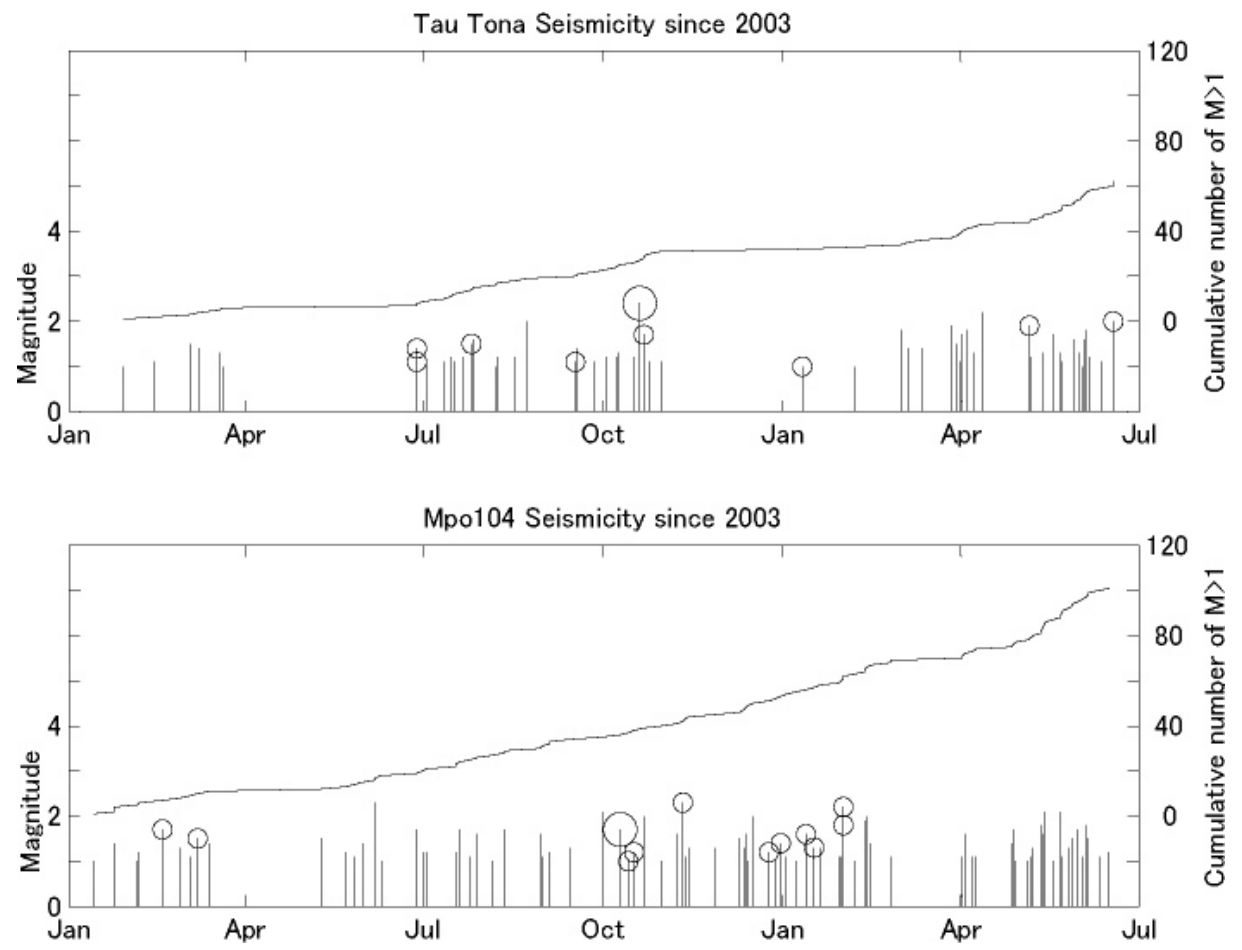

FIG. 10 Comparison with seismicity and monitoring preparation. Line: cumulative number of $M>1$ in a volume of $500 \mathrm{~m} \times 500 \mathrm{~m} \times 500 \mathrm{~m}$ centred on our strainmeter. Bar: magnitude. Larger and smaller circles: events with expected strain step $>$ about $10^{-4}$ and about $10^{-5}$ at our site, respectively 
quick drilling and installation. In consequence, we must thoroughly redesign every instrument and installation procedure for easier, smaller-diameter drilling, including easier interfaces for power-supply and data communication. Such instrumentation will ultimately result in practical, quantitative monitoring in deeper gold mining.

\section{CONCLUDING REMARKS}

Though we had difficulty in drilling at a site under very high-stress conditions, and considerable delay ensued, we successfully deployed an ideal, dense array for multidisciplinary monitoring of the entire life span of an earthquake.

\section{ACKNOWLEDGMENTS}

We are grateful to a large number of personnel at the Tau Tona and Mponeng mines, including mine captains, shift bosses, rock mechanists, geologists, surveyors, electricians and underground workers. We thank personnel of ISS International Ltd., particularly Marie Gerenger, Patrick Lenegan, Hanno Hoogenboezem, Francois Du Plessis, Talita Bacon, Jan Danilowicz, Peter Mountfort and Freddie Enslin for their kind help in the course of our project. We are also indebted to Seismogen CC for logistics, Boart Longyear Ltd. for drilling, and Techno Sugaya Co., Japan, and Makome Corp., Japan, for instrument development and set-up. This project was funded by Grants-in-aid from the Ministry of Education, Culture, Sports, Science and Technology, Japan (Nos. 14403005, 14204040, and 15340143), The Mining and Materials Processing Institute, Japan, the Earthquake Research Institute, the University of Tokyo, and Ritsumeikan University. We are also grateful to helpful comments by an anonymous referee that improved the manuscript.

\section{REFERENCES}

Amadei, B. and Stephansson, O. (1997) Rock Stress and its Measurement. Chapman \& Hall, New York, 490 pages.

Byerlee, J.D. (1978) Friction of rocks. Pure Appl. Geophys. 116: pp. 615-626. Iio, Y. (1995) Earthquake prediction in South African gold mines. Iwanami Science 65: pp. 279-281 (in Japanese).

Iio, Y. and Fukao, Y. (1992) Call for joining international experiment in South African gold mines. News Letter Seismol. Soc. Jpn. 3(6): pp. 8-9 (in Japanese).

Iio, Y., Matsuzawa, T., Yoshida, S., Kato, T. and Hirata, N. (2003) Spatial and temporal changes of aseismic slip and its role on earthquake forecasting. Zisin 2 (J. Seismol. Soc. Jpn.) 56: 213-229.

Ishii, H., Yamauchi, T. and Kusumoto, F. (1997) Development of high sensitivity bore hole strain meters and application for rock mechanics and earthquake prediction study. In Rock Stress Balkema, Rotterdam, pp. 253-258.

Ishii, H., Yamauchi, T., Matsumoto, S., Hirata Y. and Nakao, S. (2002) Development of multi-component borehole instrument for earthquake prediction study, some observed example of precursory and coseismic phenomena relating to earthquake swarms and application of the instrument for rock mechanics. In Seismogenic Process Monitoring (ed. H. Ogasawara, T. Yanagidani and M. Ando) Balkema, Rotterdam, pp. 365-377.

Kita, S., Otsuki, K., Kawakata, H., Ogasawara, H. and the Research Group for Semi-controlled Earthquake-Generation Experiment in South African Deep Gold Mines (2004) Analysis of fault rock formed by seismic slips in South Africa Gold mines, Abstract, Jpn. Seismol. Soc. Fall Meeting, pp. P026-P026.

Lachenbach, A.H. and Sass J. (1980) Heat flow and energetics of the San Andreas fault zone. J Geophys. Res. 85: pp. 6185-6222.

Matsumoto, S., Ishii, H., Yamauchi, T. and Kubota, R. (2000) Development of overcoring system in deep boreholes for in situ rock stress measurement. Tech. Res. Rep. Earthq. Res. Inst. Univ. Tokyo. 6: pp. 1-9.

McGarr, A., Sacks, I.S., Linde, A.T., Spottiswoode, S.M. and Green, R.W.E. (1982) Coseismic and other short-term strain changes recorded with Sacks-Evertson strainmeters in a deep mine, South Africa. Geophys. J. R. astr. Soc. 70: pp. 717-740.

Mendecki, A.J. (1993) Keynote address: real time quantitative seismology in mines. In Rockbursts and Seismicity in Mine (ed. R.P. Young) Balkema, Rotterdam, pp. 287-295.

Mendecki, A.J. (ed.) (1997) Seismic Monitoring in Mines. Chapman and Hall, London. 262 pages.
Nakatani, M., Yamauchi, T., Kato, A., Ogasawara, H., Ward, T., Zibi, W., Kuwano, O., Takeuchi, J., Otsuki, K., Kawakata, H., Shimoda, N., McGill, R., Iio, Y., Sumitomo, N. and the Research Group for Semicontrolled Earthquake Generation Experiment at South African Gold Mine (2004) A $3 \mathrm{~km}$ deep on-fault thermometer array for measuring the heat generated by forthcoming earthquakes in a South African gold mine, Abstract, Jpn. Joint Meeting Earth Planet. Sci., pp. S044-002.

Nicolaysen, L.O. (1992) International Semi-controlled experiment on seismic events: a review of the background and proposal. News Letter Seism. Soc. Jpn. 3(6): pp. 9-27.

Ogasawara, H., Sato, S., Nishii, S., Sumitomo, N., Ishii, H., Iio, Y., Nakao, S., Ando, M., Takano, M., Nagai, N., Ohkura, T., Kawakata, H., Satoh, T. Kusunose, K., Cho, A., Mendecki, A.J., Cichowicz, A., Green, R.W.E. and Kataka, M.O. (2001) Semi-controlled seismogenic experiments in South African deep gold mines. In Proceedings 5th International Symposium on Rockburst and Seismicity in Mines (G. van Aswegen, R.J Durrheim, W.D. Ortlepp), pp. 293-300.

Ogasawara, H. and the Research Group for Semi-controlled EarthquakeGeneration Experiment in South African Deep Gold Mines (2002) Review of semi-controlled earthquake-generation experi-ments in South African deep gold mines (1992-2001). In Seismogenic Process Monitoring (ed. H. Ogasawara, T. Yanagidani and M. Ando) Balkema, Rotterdam, pp. 119-150.

Ogasawara, H., Takeuchi, J., Shimoda, N., Ishii, H., Nakao, S., van Aswegen, G., Mendecki, A.J., Cichowicz, A., Ebrahim-Trollope, R., Kawakata, H., Iio, Y., Ohkura, T., Ando, M. and the Research Group for Semi-controlled Earthquake-generation Experiments in South African deep gold mines (2005) High-resolution Strain Monitoring During $\mathrm{M} \sim 2$ Events in a South African Deep Gold Mine in Close Proximity to Hypocentres. In Proc. RaSiM6 - 6th Int. Symp. on Rockburst and Seismicity in Mines. Y. Potvin and M.R. Hudyma (eds.), Australian Centre for Geomechanics, March 2005.

Ryder, J.A. and Jager, A.J. (1999) A Handbook on Rock Engineering Practice for Tabular Hard Rock Mines. SIMRAC, Johannesburg, South Africa, 371 pages.

Ryder, J.A. and Jager, A.J. (2002) A Textbook on Rock Mechanics for Tabular Hard Rock Mines. SIMRAC, Johannesburg, South Africa, 489 pages.

Sumitomo, N. (1998) International joint research: semi-controlled earthquake generation experiment. Chikyu monthly. 229: pp. 391-394 (in Japanese).

Takeuchi, J., Ogasawara, H., Ishii, H., Nakao, S., Ando, M., van Aswegen, G., Mendecki, A.J., Cichowicz, A., Mountfort, P., Ide, S., Kawakata, H. and the Research Group for Semi-controlled Earthquake-generation Experiments in South African Deep Gold Mines (2003) Coseismic strain change of $10-4$ and $7 \times 10-5$ recorded with Ishii strainmeter by continuous $24 \mathrm{bit} 25 \mathrm{~Hz}$ monitoring on seismic fault of $\mathrm{M} \sim 3$ in deep gold mine, South Africa, Eos Trans. AGU, 84(46), Fall Meet. Suppl., Abstract S41C-0103, 2003.

Yamauchi, T., Ishii H. and Matsumoto, S. (2000) Development of an intelligent type strainmeter for in situ stress measurement in deep boreholes. Proc. Soc. Expol. Gephys. Jpn. 102: pp. 104-108. 